\title{
The Analysis of Factors Affecting Interest in Fertile Age Women in Performing Early Detection of Cervical Cancer at Community Health Center Kubutambahan I Buleleng Regency-Bali
}

\begin{abstract}
Putu Indah Sintya Dewi

Magister of Public Health Program of Institut Ilmu Kesehatan STRADA Indonesia

Email:

indahsintya88@gmail.com

Received : October 12, 2019

Accepted : February 13, 2020

One effort to prevent cervical cancer is to do early detection of cervical cancer, but often this is ignored because of lack of knowledge, interest and information on early detection of cervical cancer. This study aimed to analyze the influence of the characteristics of FAW, attitudes and subjective norms of FAW on the interest of early detection of cervical cancer at Community Health Center Kubutambahan I. This type of research was an observational analytic cross-sectional design study. The population in this study FAW who visited at Community Health Center Kubutambahan I with a sample of 104 FAW sampling technique that was simple random sampling. Bivariate data analysis used chi square statistical tests and multivariate analysis used logistic regression. The results of this study that there is a knowledge factor influencing interest with a p-value of 0.023 $<0.05$, attitude factor influencing interest with a p-value of 0.023 $<0.05$, there are subjective norm factors influencing FAW interest in detecting cervical cancer with $\mathrm{p}$-value $0.016<0.05$ and educational and occupational factors do not affect FAW interest in detecting cervical cancer with p-value $>0.05$. The conclusion of this study did not significantly influence education and employment factors with a $\mathrm{p}$ value $>0.05$. While knowledge, attitudes and subjective norms are factors that influence significantly with a $\mathrm{p}$ value $<0.05$. The dominant factor influencing FAW's interest in early detection of cervical cancer is subjective norm.
\end{abstract}

Published : May 12, 2020
Keywords: Cervical Cancer, FAW, Knowledge, Attitude, Interest

\section{(c) (1) ( $(9)$}

This is an open-acces article distributed under the terms of the Creative Commons Attribution-ShareAlike 4.0 International License. 


\section{INTRODUCTION}

Reproductive health is a state of complete physical, mental and social well-being, not solely free from disease or disability in all matters relating to the reproductive system and its functions and processes. One of the reproductive organs of women who are susceptible to cancer is the cervix and is called cervical cancer. Cervical cancer or often known as cervical cancer is cancer that occurs in the uterine cervix, an area in the female reproductive organs which is the entrance to the uterus located between the uterus and intercourse. As an alternative screening test, Visual Acetic Acid Inspection (VAAI) was chosen as a method for detecting cervical cancer because it has several benefits, is more effective and efficient, compared to other cervical cancer screening methods such as pap smears or HPV-DNA tests. Indonesian women's awareness to conduct early detection of cervical cancer regularly is still low. According to national data the screening coverage for Visual Acetic Acid Inspection (VAAI) is still very low (around 5\%).

Knowledge is the result of human sensing, or the result of knowing someone about objects through their senses (eyes, nose, ears, etc.) (Notoatmodjo, 2010: 50). While attitude is a closed response to a stimulus or object that already involves the opinions and emotions of the person concerned, for example happy or unhappy, agree or disagree, and so on while subjective norms are one's perception of social pressure to display or not display behavior behavior. So that knowledge, attitudes and subjective norms shape a person's behavior that leads to positive change. Positive behavior of women of childbearing age in maintaining their health, especially reproductive health is early detection. One of them is early detection of cervical cancer, through VAAI exaInteres ion. To increase efforts for early detection of cervical cancer, interest greatly affects women of childbearing age. Interest is a source of motivation that encourages a person to do what he wants if that person is given the freedom to choose. The tendency of people to be interested in an experience and to continue to be so (Hurlock, 1995). This research aims to analyze the factors that influence the interest of fertile women in early detection of cervical cancer at Community Health Center Kubutambahan I and analyze characteristics (knowledge, education and occupation), attitudes, subjective norms of FAW towards FAW interest in early detection of cervical cancer.

\section{METHODS}

This research is an observational analytic study by using cross-sectional design. This research was conducted at Community Health Center Kubutambahan I, Buleleng Regency. The time of research and data collection began on December 16, 2019 - January 16, 2020. The population was all women of childbearing age at Community Health Center Kubutambahan I area in 2019. The population found during the initial preliminary study was 385 FAW. Sample this study used a cross-sectional formula with a double proportion found that the sample is 104, with the dependent variable being the interest of early detection of cervical cancer at Community Health Center Kubutambahan I and the independent variable (independent) in this study were the characteristics (education, occupation, knowledge), the attitudes and subjective norms of FAW at Community Health Center Kubutambahan I, which will be analyzed by using bivariate, data analysis by using chi square statistical tests and multivariate analysis used statistical tests namely logistic regression.

\section{RESULTS \\ Description of Research Sites}

Community Health Center Kubutambahan I was built in 1976 on the land owned by the Kubutambahan village of $1,540 \mathrm{~m} 2$ with ownership rights to use land with an area of $344.85 \mathrm{~m} 2$ of Public Health Centre. at Community Health Center Kubutambahan I consists of 5 villages namely Kubutambahan Village, Bukti Village, Bulian Village, Bengkala Village, and Depeha Village. The furthest distance from the village to the Public Health Centre is $10 \mathrm{~km}$, each village can be reached by 2-wheeled or 4-wheeled vehicles. 
Data Analysis Description

Table 1 Frequency distribution of the characteristics of Respondents at Community Health Center Kubutambahan I

\begin{tabular}{lc}
\hline Characteristics of Respondents & Percentage $(\boldsymbol{\%})$ \\
\hline Age (Mean \pm SD) & $31,67 \pm 5,8$ \\
\hline Education & $71(68,3)$ \\
High & $33(31,7)$ \\
Low & $\mathbf{1 0 4}(\mathbf{1 0 0})$ \\
\hline Total & \\
\hline Profession & $57(54,8)$ \\
$\quad$ Work & $47(45,2)$ \\
$\quad$ Not Working & $\mathbf{1 0 4}(\mathbf{1 0 0})$ \\
\hline Total & $63(60,6)$ \\
\hline Knowledge & $41(39,4)$ \\
Good & $\mathbf{1 0 4}(\mathbf{1 0 0})$ \\
Less &
\end{tabular}

Univariate analysis results found that based on table 1 the average age of respondents was in the age range of 31 years, with a standard deviation of 5.8. Most of the respondents with a high education, who graduated from high school to university, were 71 people $(68.3 \%)$. The majority of respondents work, as many as 57 people $(54.8 \%)$. The results of this study report that the types of FAW work are various. Starting from joining her husband as a fisherman, a seller in the market, working in an office and others. Most of the respondents were well-informed in relation to early detection of cervical cancer in 63 people $(60.6 \%)$.

Table 2 Analysis of Characteristics (Knowledge, Education and Occupation) of Interest in Fertile Women in Performing Early Detection of Cervical Cancer

\begin{tabular}{lccc}
\hline \multirow{2}{*}{ Percentage } & \multicolumn{2}{c}{ Interest } & p-value \\
\cline { 2 - 3 } & Interested & Not Interested & \\
\hline Education & & & \\
$\quad$ High & $40(56,3)$ & $31(43,7)$ & 0,2 \\
Low & $23(69,7)$ & $10(30,3)$ & \\
\hline Profession & & & \\
$\quad$ Work & $35(61,4)$ & $22(38,6)$ & 0,8 \\
$\quad$ Tidak & $28(59,6)$ & $19(40,4)$ & \\
\hline Knowledge & & & \\
$\quad$ Good & $49(72,1)$ & $19(27,9)$ & $0,001^{*}$ \\
$\quad$ Less & $18(45,0)$ & $22(55,0)$ & \\
\hline
\end{tabular}

Data source: Primary data (2019)

Table 2 shows the results of the bivariate analysis of independent variables with the interest of FAW who are interested in early detection of cervical cancer. Education and employment variables are not significant variables with $\mathrm{p}>0.05$. While the bivariate analysis of knowledge found a value of $\mathrm{p}<$ 0.05 , which means that knowledge influences bivariate with an interest in FAW doing early detection of cervical cancer. Respondents who have high knowledge as many as 49 people $(72.1 \%)$ are interested in conducting early detection of cervical cancer. 
Table 3 Analysis of Attitudes of Fertile Age Women towards Interest in Fertile Age Women in Performing Early Detection of Cervical Cancer

\begin{tabular}{cccc}
\hline \multirow{2}{*}{ Variable } & \multicolumn{2}{c}{ Interest } & \multirow{2}{*}{ P-value } \\
\cline { 2 - 3 } & Interested (\%) & Not Interested (\%) & \\
\hline Attitude & & & \multirow{2}{*}{$0,003^{*}$} \\
Positive & $49(70,0)$ & $21(30,0)$ & \\
Negative & $18(47,4)$ & $20(52,6)$ & \\
\hline
\end{tabular}

Data source: Primary data (2019)

Table 3 found that a positive attitude responded to 49 respondents (70\%) interested in early detection of cervical cancer. This result is also bivariate significant with a $p$ value $<0.05$. So this variable can be entered into the regression model.

Table 4 Subjective Norm Analysis of Interest in Fertile Age Women in Performing Early Detection of Cervical Cancer

\begin{tabular}{lccc}
\hline \multirow{2}{*}{ Variable } & \multicolumn{2}{c}{ Interest } & \multirow{2}{*}{ P-value } \\
\cline { 2 - 3 } & Interested & Not Interested & \\
\hline Subjektive Norms & & & \multirow{2}{*}{$0,002^{*}$} \\
Positive & $40(76,9)$ & $12(23,1)$ & \\
Negative & $27(48,2)$ & $29(51,8)$ & \\
\hline
\end{tabular}

Data source: Primary data (2019)

Table 4 found that subjective norms were positive for as many as 40 people (76.9\%) interested in early detection of cervical cancer.

Table 5 Analysis (Knowledge, Education and Occupation), Attitudes and Subjective Norms of Fertile Age Women towards Interest in Fertile Women in Performing Early Detection of Cervical Cancer

\begin{tabular}{|c|c|c|c|c|c|c|}
\hline \multirow[b]{2}{*}{ Variable } & \multicolumn{2}{|c|}{ Interest } & \multirow[b]{2}{*}{ P-value } & \multirow[b]{2}{*}{ OR } & \multicolumn{2}{|c|}{ CI } \\
\hline & Interested & Not Interested & & & Lower & Upper \\
\hline \multicolumn{7}{|l|}{ Education } \\
\hline High & $40(56,3)$ & $31(43,7)$ & 0,269 & 1,7 & 0.65 & 4,6 \\
\hline Low & $23(69,7)$ & $10(30,3)$ & & & & \\
\hline \multicolumn{7}{|l|}{ Profession } \\
\hline Work & $35(61,4)$ & $22(38,6)$ & 0,870 & 0,9 & 0,3 & 2,7 \\
\hline Tidak & $28(59,6)$ & $19(40,4)$ & & & & \\
\hline \multicolumn{7}{|l|}{ Knowledge } \\
\hline Good & $49(72,1)$ & $19(27,9)$ & $0,023^{*}$ & 2,8 & 1,1 & 7,0 \\
\hline Less & $18(45,0)$ & $22(55,0)$ & & & & \\
\hline \multicolumn{7}{|l|}{ Attitude } \\
\hline Positive & $49(70,0)$ & $21(30,0)$ & $0,023^{*}$ & 0,3 & 0,1 & 0,8 \\
\hline Negative & $18(47,4)$ & $20(52,6)$ & & & & \\
\hline \multicolumn{7}{|l|}{ Subjektive } \\
\hline \multicolumn{7}{|l|}{ Norms } \\
\hline Positive & $40(76,9)$ & $12(23,1)$ & $0,016^{*}$ & 0,3 & 0,1 & 0,8 \\
\hline Negative & $27(48,2)$ & $29(51,8)$ & & & & \\
\hline
\end{tabular}

Results Table 5 based on the simultaneous test of the Characteristics, Attitudes and Subjective Norms of FAW Interests Conduct Early Detection of Cervical Cancer that knowledge variable, attitudes 
and subjective norms affect interest with a $\mathrm{p}$ value $<0.05$. So this variable can be entered into the regression model in multivariate analysis.

Table 6 Analysis of Dominant Factors Affecting the Interest of Fertile Women in Performing Early Detection of Cervical Cancer

\begin{tabular}{lcccc}
\hline \multirow{2}{*}{ Variable } & \multirow{2}{*}{ AOR } & \multirow{2}{*}{ P-value } & \multicolumn{2}{c}{$95 \%$ CI } \\
\cline { 4 - 5 } & & & Lower & Upper \\
\hline Knowledge & 0,3 & 0,025 & 0,1 & 0,8 \\
\hline Attitude & 2,9 & 0,020 & 1,1 & 7,2 \\
\hline Subjektive Norms & 3,1 & $0,013^{*}$ & 1,2 & 7,7 \\
\hline *Uji statistik Nominal Regresi Logistik level of signifikan 0,05 & & &
\end{tabular}

Table 6 above found that the dominant variable significantly affected was subjective norms with a p-value of $0.013<0.05$ with AOR 3.1, which means there was a 3 times chance to increase respondents' interest in detecting early cervical cancer rather than knowledge and attitude variables which attitude variable has a 2 times more chance to increase interest in early detection of cervical cancer and knowledge of less than one (1) has the opportunity to increase interest in early detection of cervical cancer.

\section{DISCUSSION}

Characteristics of Respondents (Education, Employment and Knowledge) of the Interest of Fertile Women in Performing Early Detection of Cervical Cancer

There is an influence of knowledge variable which is a characteristic of respondents with a $p$ value of $0.023<0.05$ which means that knowledge significantly influences the interest of FAW in early detection of cervical cancer. Whereas education and occupation variables that did not significantly influence the interest of FAW did early detection of cervical cancer with a value of $p>0.05$. So that respondents who have high knowledge as many as 49 people (72.1\%) are interested in doing early detection of cervical cancer.

Respondent characteristics in this study include age, education, and occupation of FAW in Kubutambahan Village. The results found were the respondents in this study were in the age range of 31 years. Previous results also found that respondents who entered the research in Ambon City were related to the interest in early detection of cervical cancer mostly in the age range of 30 years and above (Rahakbauw, 2018). These results indicate that the majority of respondents are of sufficient age, which indicates a person will be more mature in thinking and working. Cervical cancer can strike at a young age but when it reaches maturity then the symptoms of cervical cancer will begin to feel. One indication of cervical cancer is marriage and early sexual intercourse at the age of less than 20 years (Masturoh, 2016).

The education of the respondents in this case was mostly educated last from high school to university which could be called tertiary education. This result is in line with research in Semarang that most of the respondents' education was highly educated, 47.6\% (Ulfiana, 2013). Education is very influential on something that comes from outside. Then higher education will provide a more rational response to the information that comes and will think to what extent the benefits might be derived from the idea (Ulfiana, 2013). A woman's education is also related to the socioeconomic level and lifestyle that she lives, for example matters relating to knowledge about hygiene and health and sexual life behavior (Masturoh, 2016).

In line with the theory that work is also a factor that indirectly requires respondents to make early detection of cervical cancer. This interest arises when the respondent feels that there is an income in him. To make early detection of cervical cancer an attempt is made by the respondent to conduct early detection and this is very influential on the willingness of mothers to do early detection. Families with low economic status naturally rule out the need for information that is not a primary need (Ulfiana, 2013).

After a bivariate analysis it was found that education and employment could not be included in the multivariate analysis model. So that the variables that enter dominantly affect FAW's interest in 
conducting early detection are Knowledge. The results of this study found that high knowledge was 0.3 times more likely to increase the interest of respondents to conduct early detection of cervical cancer. The results of previous studies also found the same thing that knowledge is one of the factors that can increase the interest of FAW to conduct early detection of cervical cancer, so that with good knowledge, FAW can choose and understand the importance of early detection of cervical cancer for its health (Rahakbauw, 2018).

Lack of knowledge of respondents about cervical cancer caused by respondents less exposed to information about cervical cancer both from print media, electronic media and lack of involvement in socialization and outreach activities conducted in the community. The occurrence of forgetfulness or not remembering someone about the information that was received, among others, is caused by several things, namely psychological (do not like the information), information is not used for a long time so there is a tendency to blur or disappear from memory, new information tends to obscure or eli Interes e old information that has not long been embedded in someone's memory (Narhasanah, 2008). Many things can be done to improve the knowledge of FAW for early detection of cervical cancer, for example by doing counseling, counseling, putting up posters, giving posters to giving leaflets related to early detection of cervical cancer. Provision of this information is very important especially done by health workers who can recommend an exaInteres ion conducted for early detection of cervical cancer (Triutomo, 2017).

\section{Attitudes of Fertile Age Women towards Interests of Fertile Age Women in Performing Early Detection of Cervical Cancer}

There is an influence of attitude towards FAW interest in performing early detection of cervical cancer with a $\mathrm{p}$ value of $0.023<0.05$. The results of this study are in line with the results of previous studies conducted by Ardi Ningsih, Ninik (2011) also found the same thing that there is a meaningful relationship between the attitudes of FAW to the early detection intentions of cervical cancer, finding that FAW who has a positive attitude will increase their interest to detect premature cervical cancer. Based on the theory of attitude is a certain order in terms of feelings (affection), thought (cognition), and predisposition of action (konasi). Someone about an aspect in the surrounding environment (Azwar, 2007). Someone is not born with attitudes and views, but these attitudes are formed throughout its development. Where in social interaction, individuals react to form certain patterns of attitude towards various psychological objects that they face (Azwar, 1995).

Factors that influence attitudes are personal experience, culture, other people who are considered important, mass media, educational institutions and religious institutions, as well as emotional factors in individuals. Various forms of mass media such as television, radio, newspapers, and others have a great influence on the formation of people's opinions and beliefs. The mass media gives a suggestive message that directs one's opinion. The existence of new information about something provides a new cognitive basis for the formation of attitudes towards it. If strong enough suggestive messages will provide an affective basis in assessing things so that the formation of a certain attitude.

Based on the analysis of researchers from the results of respondents' answers about the attitude point towards FAW interest in performing early detection of cervical cancer that the respondent strongly agreed to do early detection with IVA, but there are a number of things that cause respondents not to do VAAI exaInteres ion because there is still a sense of shame to do the exaInteres ion with lithotomy position. Then the respondent also considers that the health worker, especially the midwife, is not yet skilled in conducting VAAI exaInteres ions.

So that the attitude here is formed from FAW who consider themselves vulnerable to the occurrence of something undesirable. So that their perceptions will make their attitudes more positive towards themselves to avoid illness (Umriaty and Setia, 2017). It can be concluded that the higher the value of the attitude of FAW, the stronger the interest of FAW in early detection of cervical cancer, and vice versa the lower the value of the attitude of FAW, the lower the interest of FAW in early detection of cervical cancer 


\section{Subjective Norms of Fertile Age Women Against Interests of Fertile Age Women in Performing Early Detection of Cervical Cancer}

There is a significant relationship between subjective norms and interests in early detection of cervical cancer. The more positive subjective norms of FAW will increase the interest of FAW to conduct early detection of cervical cancer. The results of previous studies also found the same results that subjective norms are associated with increased interest in FAW for early detection of cervical cancer (Umriaty and Setia, 2017).

This proves that subjective norms significantly affect FAW interest in early detection of cervical cancer. FAW still believes in the support of existing families because there are still moral values in each family member which is the motto of the life of each family member. Subjective norms are the third variable that can affect FAW interests. This subjective norm is defined as a person's perception of the expectations of "significant others" to do a certain behavior (Fishbean and Ajzen, 1995).

This means that FAW who have positive subjective norms are influenced by those closest to the respondent (husband, parents, and friends) so as to provide an impetus for early cervical cancer detection. Indirectly, besides attitude, there are significant subjective norms that are also related to increasing FAW interest. This means that beliefs about what other people want us to do. This subjective norm is formed from several components, namely self-efficacy in the form of one's own ability to change a behavior. Then the effectiveness response is a person's belief that the recommended behavior will be effective in reducing or eliminating danger. This response will effectively influence a person to change his behavior as recommended. Other components are vulnerability in the form of vulnerability as an unwanted result and severity as the level of gravity or the way someone views the danger and whether or not a disease.

\section{Dominant Factors Affecting Interest in Fertile Women in Performing Early Detection of Cervical Cancer}

The dominant factor influencing significantly is subjective norm with a p-value of $0.013<0.05$ with AOR 3.1, which means there is a 3 times chance to increase the interest of respondents in the early detection of cervical cancer rather than knowledge and attitude variables where the attitude variable has a 2 chance times more increasing interest in early detection of cervical cancer and knowledge of less than one (1) has the opportunity to increase interest in early detection of cervical cancer. Logistic regression test with enter method on the influence of knowledge, attitudes, subjective norms simultaneously influences the intention or interest of FAW in early detection of cervical cancer. This means that knowledge, attitudes, subjective norms can simultaneously be used as predictors of the emergence of intention or interest in early detection of cervical cancer. But the most dominant influence is subjective norm factor. It can be concluded that the higher the confidence of perception of the ability to control decisions, the better the perceived personal interest. Conversely, if the person feels unsure and unable, then what is perceived by the person will be bad.

Educational and occupational factors did not significantly affect the interest of FAW in carrying out early detection of cervical cancer because statistically through the chi square test that there was no significant effect with a p-value> 0.05. In accordance with the opinions expressed (Masturoh, 2016) that a woman's education is also related to the socioeconomic level and lifestyle that she lives, for example matters relating to knowledge about hygiene and health and sexual life behavior, statistical results that do not significantly influence knowledge causes the education factor is only a title in someone's diploma. So that the influence is the knowledge and information possessed.

While the respondent's occupational factors at Community Health Center Kubutambahan I were mostly working, with the working conditions of the respondents being unable to have time to make visits and conduct early detection of cervical cancer. Indeed, work is a factor that indirectly requires respondents to make early detection of cervical cancer. This interest arises when the respondent feels that there is an income in him. To make early detection of cervical cancer an attempt is made by the respondent to conduct early detection and this is very influential on the willingness of mothers to do early detection. Families with low economic status naturally rule out the need for information that is not a primary need (Ulfiana, 2013). 


\section{CONCLUSION}

Based on the results of research that has been done, the following conclusions can be drawn:

1. Education and employment in bivariate have no significant effect with Education $p$ value of $0.26>$ 0.05 , and occupation value of $\mathrm{p}$-value of $0.87>0.05$ Whereas bivariate knowledge is a significant factor with $\mathrm{p}$ value of $0.023<0.05$.

2. FAW attitude significantly influence bivariate analysis with $\mathrm{p}$ value $0.023<0.05$

3. Positive subjective norms on FAW also influence bivariately with FAW interest in conducting early detection with a $\mathrm{p}$ value of $0.016<0.05$

4. There is an influence of knowledge, attitudes and subjective norms on the interest of FAW early detection with $\mathrm{p}<0.05$

5. The dominant factors influencing FAW interest in early detection of cervical cancer are Subjective Norms with $\mathrm{p}$ values 0.013 and AOR: $3.195 \%$ CI 1.2-7.7 which means subjective norms of positive FAW have a 3 times chance of increasing FAW interest in conducting early detection of cervical cancer

\section{REFERENCES}

Ajzen, I. 1988. From Intention to Actions, Attitudes, Personality and Behavior. London: Open University Press, England

Ajzen I. 1991. The Theory of Planned Behavior. Organizational Behavior and Human decision Processes. Academic Press, University of Massachusetts

Andrijono. 2007. Cervical Cancer. Oncology Division. Dept. Obstetrics Gynecology FKUI. Issue I. Jakarta. FKUI Publisher Center

RI POM Agency. 2012. Module Basic Concepts of Communication, Information, and Education. RI BPOM. Jakarta

Colo G. A. 1996. Management, Theory, and Practice. Lets Educational Aldine. London

RI Ministry of Health. 1994. Technical Guidelines for Implementing Midwives Appointment as Nonpermanent Employees. Ministry of Health Republic of Indonesia. Jakarta

RI Ministry of Health. 2009. Handbook of Prevention of Cervical Cancer \& Breast cancer. Ministry of Health Republic of Indonesia. Jakarta

Desbi J. 2015. Using Cervical Cancer Screening Through the IVA Method. Journal of Unsri Vol. 2 No. 2

Ferlay. I. GLOBOCAN. 2008. Cancer Indence and Mortality World wide. IARC Cancer Base no.10: Lyon. France. 2010

Hikmawati I. 2011. Health Promotion for Midwifery. Yogyakarta: Nuha Mendika

Laras, L. 2009. Analysis of Risk Factors for Cervical Cancer. FKUI: Jakarta

L Feriyawati, D R Anggraini1, A A Fitrie and R N Anggreini. 2018. Knowledge of cervical cancer, attitude and husband's support of Pap smear among multiparous women who have Pap's smear exaInteres ion in Aviati clinic Padang Bulan Medan. IOP Conf. Series: Earth and Environmental Science

Maharani, R., \& Syah, C. V. (2019). Early Detection Cervical Cancer Behavior by ExaInteres ion of Iva by Fertile Women in Sorek Satu Village, Pangkalan Kuras Health Center, Pelalawan Regency. Avicenna, 14 (01), 288235.

Maharsie, L. 2012. Participation as well as Mothers Conducting IVA Test in Jebres Village. Journal of Stikes Aisyiyah Vol. 9 No. 2

Makmuri. 1999. Organizational behavior, Post Graduate Education Program in Management of the University of Gajah Mada Hospital, Yogyakarta

Masturoh, E. (2016) Factors Affecting Fertile Women (FAW) in Performing Early Detection of Cervical Cancer Visual Acetate Acid (IVA) Visual Inspection Method, Semarang State University.

Meutia, S. 2008. Pre-cancer and Cervical Cancer Manual of Uterus. Jakarta: Gramedia

Monica, BR, Widjanarko, B. and Prabamurti, PN (2019) 'Relationships of Knowledge, Subjective Norms and Perception of Behavioral Control with the Intention of Housewives at Risk of HIV 
in Accessing VCT Services', Journal of Public Health (e-Journal), 7 (4 ), pp. 496-503. Available at: https://ejournal3.undip.ac.id/index.php/jkm/article/view/24924.

Murti B. 1997. Principles and Methods of Epidemiological Research. UGM: Yogyakarta

Murti B. 2010. Design and Sample Size for Quantitative and Qualitative Research in the Field of Health. Second Edition. UGM: Yogyakarta

Narhasanah, C. (2008) Effect of Characteristics and Behavior of Fertile Age Pairs on Pap Smear ExaInteres ions at Banda Aceh Hospital.

Notoatmodjo, S. 2010. Health Behavioral Sciences. Jakarta: Rineke Cipta

Notoatmodjo, S. 2012. Health Research Methodology. Jakarta: Rineke Cipta

Nurwijaya, H. 2010. Prevent and Detect cervical cancer. Jakarta: Elek Media Kompurtindo

Nirmala Ahmad, Siswanto. 2010. The Effect of Motivation on Increasing Competence of Village Midwives in Malang District. Buletin Health System Research Vol. 13 No. 1. January 2010 page 8081

Ni Made Sri Dewi 1. Relationship between knowledge and attitude of FAW with IVA exaInteres ion at Public Health Centre Buleleng 1. Journal of Family Medicine Masters. 1 No. 1 (pp. 57-66)

NA Pangesti.2012. Characteristic Description of Fertile Age Women (FAW) Who Perform Visual Acetate Acid Inspection (IVA) at Karanganyar Health Center. Scientific Journal of Nursing Health, Volume 8, No. 2

Rahakbauw, G. Z. (2018) 'Relationship between Knowledge about Cervical Cancer and the Intention of Fertile Women to Conduct Pap Smear ExaInteres ion in the Prevention of Cervical Cancer in Kudamati Sub-District, Nusaniwe District, Ambon City, Global Health Science, 4 (3), pp. 339-345.

Rasjidi, I. 2009. Epidemiology of Cervical Cancer. Indonesian Journal of Cancer Vol. 3 No. 3

Rengaswamy Sankaranarayanan, Atul Madhukar Budukh, \& Rajamanickam Rajkumar. 2001. Effective screening programs for cervical cancer in low- and middle-income developing countries. Bulletin of the World Health Organization, 79 (10).

RM Fauziah. 2011. Early Detection of Cervical Cancer in Primary Service Centers in Five Areas of DKI Jakarta. Medical Research Article, University of Indonesia. Jakarta.

Septadina.2015. Efforts to Prevent Cervical Cancer Through Increasing Women's Reproductive Health Knowledge and ExaInteres ion of IVA Method. Sriwijaya Devotion Journal Vol. 3 No. 1

Sidohutomo., A., 2011. I, Angel, \& Literature. Women Can Prevent Cervical Cancer. Surabaya: Gramedia

SN Mayrita. 2015. Relationship between Parity and Cervical Cancer Occurrence at the Wisnuwadhana Cancer Foundation in Surabaya. Scientific Journal of Health Vol. 8 No. 1 (pp. 8-14)

Sukaca, BE. 2009. Smart Ways to Deal with Cervical Cancer (Cervix) 